\title{
Expertise in Automatism Study: An Application in the Consumption of Esthetics ${ }^{1}$
}

\author{
Amalia Raquel Pérez-Nebra² \\ Centro Universitário de Brasília, \\ Brasília-DF, Brazil
}

\author{
Claudio Vaz Torres \\ Universidade de Brasilia, \\ Brasília-DF, Brazil
}

\begin{abstract}
Expertise is one of the ways one can make one's behaviors become automatic, and with consumption it is no different. Explanatory models of this sort of behavior described in the literature up to now have considered only conscious or rational buying, and do not apply to automatic buying. The model proposed here is inspired by, and adapted from, the behavior analyses, integrating variables that have typically been neglected in the traditional models, such as contextual variables. This study aimed to describe the relationship between the reports of behavior linked to the consumption of esthetics (operationalized in four variables: commenting, getting information, using cosmetic products and services) and the individual variables and those of the setting where purchases related to beauty were made. In order to do so, 953 Brazilian women responded to an online questionnaire. The model was tested and partially confirmed. Contextual socialpsychological variables were the only ones to predict routine buying. Demographic and individual variables did not account for the variance explanation of the behaviors measured. It is suggested that further studies should use and contribute to this model to enhance the understanding of automatic buying.
\end{abstract}

Keywords: esthetics, consumer behavior, automatism

\section{Expertise no Estudo de Automatismo: Uma Aplicação em Consumo de Estética}

\begin{abstract}
Resumo: A rotina é uma das formas de automatizar comportamentos e em consumo não é diferente. Os modelos explicativos de compra descritos na literatura partem de compras conscientes ou racionais e não se aplicam às automáticas. O modelo proposto aqui é inspirado e adaptado da análise do comportamento e trata de integrar outras variáveis tipicamente negligenciadas nos modelos tradicionais, incluindo variáveis contextuais. $\mathrm{O}$ objetivo deste estudo foi descrever a relação entre os relatos de comportamentos ligados ao consumo de beleza (operacionalizados em quatro variáveis: comentar, informar-se, usar produtos e serviços cosméticos) e as variáveis individuais e de cenário de compra direcionadas à beleza. Para isso, responderam a um questionário online 953 mulheres brasileiras. O modelo foi testado e parcialmente confirmado. As variáveis psicológicas contextuais sociais foram as únicas que predisseram os comportamentos de compra rotineira. As variáveis demográficas e as individuais não entraram como variáveis explicativas em nenhum dos comportamentos mensurados. Sugere-se que novos estudos utilizem e contribuam para este modelo no intuito de auxiliar no entendimento da compra automática.
\end{abstract}

Palavras-chave: estética, comportamento do consumidor, automatismo

\section{Expertise en el Estudio de Automatismo: Una Aplicación en el Consumo de Estética}

\begin{abstract}
Resumen: La rutina es una de las formas de automatizar la conducta y en consumo no es diferente. Los modelos explicativos de compra descritos en la literatura son de compras conscientes o racionales y no se aplican a las automáticas. El modelo propuesto aqui es inspirado y adaptado de la análise de la conducta y trata de integrar otras variables tipicamente negligenciadas en los modelos tradicionales, incluyendo variables contextuales. La finalidad de este estudio fue describir la relación entre los relatos de conductas vinculadas al consumo de estética (operacionalizadas en cuatro variables: comentar, informarse, usar productos y servicios cosméticos) y las variables individuales y de contexto de compra dirigidas a la estética. Contestaron a un cuestioário online 953 mujeres brasileñas. El modelo fue testado y parcialmente confirmado. Las variables psicológicas contextuales sociales fueron las únicas que predijeron las conductas de compra rutinera. Las variables demograficas e individuales no entraron como variables explicativas en ninguno de las conductas medidas. Sugiérese que nuevos estúdios utilicen y contribuyan para este modelo en el intuito de auxiliar en el entendimento de compra automática.
\end{abstract}

Palabras clave: estética, conducta del consumidor, automatismo

\footnotetext{
${ }^{1}$ Article derived from the doctoral dissertation of the first author, under the supervision of the second author, defended in the Graduate Program in Social, Work and Organizational Psychology, of the University of Brasilia, in 2010. Acknowledgements: Moema Brasil Dias, Jorge Mendes Oliveira-Castro and Hartmut Günther for reading the original of this work, and Renata Cambraia, Renato Arthur Franco Rodrigues, Raquel Mayrink, André Carvalho, Natasha Macedo and Clarice Beckmann for help with data collection.

Support: The Coordination for the Improvement of Higher Education Personnel (CAPES) and the National Council for Scientific and Technological Development (CNPq).

2 Correspondence address:

Amalia Raquel Pérez-Nebra. SEPN 707/907. Campus do UniCEUB, bloco 9, Asa Norte.CEP70790-075.Brasília-DF, Brazil.E-mail:pereznebra@gmail.com
}

Some reviews on decision-making processes suggest that these occur along a continuum, ranging from conscious, deliberate and intentional through to unconscious, automatic and non-intentional (Chartrand \& Fitzsimons, 2011; Dijksterhuis, 2010; Fiske \& Taylor, 2008). In this regard, the models used for decision-making in buying are based on this paradigm of controlled problem-solving. This rational and controlled model of decision-making was elaborated by economists in the 1950s and 1960s and was based on the 
assumption of the model of the Rational Choice (Chartrand \& Fitzsimons, 2011; Sternberg, 2008).

This paradigm of conscious problem-solving seems to be valid, although limited to a spectrum of choice perceived as high risk. Life does not usually require each choice to be thoroughly evaluated (Chartrand, 2005; Chartrand \& Fitzsimons, 2011). For example, if we think about beauty products, we may suppose that buying a hair dye for the first time may require some cognitive effort due to the risk and insecurity. Once the consumer knows the brand and color which suit her profile best, as she passes along the shelf and gets the box with the dye, she is probably thinking about the weekend and what she will wear, instead of paying attention to the buying process which she has just undertaken. That is to say, the resolution of this problem - buying hair dye ceased to be strictly conscious.

The data and the discussions in the literature suggest that in our routine purchases, various of the steps described in the classical models of buying behavior do not occur (Bos, Dijksterhuis, \& van Baaren, 2011; Chartrand, 2005; Chartrand \& Fitzsimons, 2011). Although some theoreticians disagree (Simonson, 2005), it means that for routine purchasing, the individual takes advantage of the clues from the environment or from the purchasing setting, in order to perform the behavior of making a purchase. Returning to the previous example, the behavior of buying a hair dye can be interpreted as problem resolution, which will make the woman who does it frequently into an expert. Therefore, the act of consuming is the act of resolving a problem, including 'to consume', as a generic term for buying, paying etc. This being so, it is worth visiting this area's literature.

Problem resolution is a mental process understood as processual or procedural. Anderson (2004) argues that the cognitive activities seem, fundamentally, to be problem resolution. There are three characteristics which define the resolution of a problem: (a) the direction towards a goal (e.g., a value, a belief, satiety etc.); (b) separation into sub-goals, for the achieving of the greater goal, which are possible to resolve; and (c) application of operators. The operators are the most elementary behaviors that the individual presents in her repertoire and which were learnt, and the resolution of the problem occurs in the finalizing of the sequence of these known operators.

It is common for problem resolution to be associated with some complicated process (Anderson, 2004) (e.g., resolution of structural calculations), but this association is inappropriate. The resolution of the problem may be related to something much more automatic. The problem may be to seek some object at home. In order to resolve it, it is necessary to put one's glasses on in the morning, a behavior which, for those who use corrective lenses, tends to be automatic. Here is the difficulty in the literature on the buying process, as it is based on a conscious purchase of rigid steps, and there is no possibility for adapting the model proposed for a process that is more automatic. This automatized process is understood here as being the consumer's expertise. There is enormous discussion in the literature on the interpretation of this automatization, which goes beyond the scope of the present work (Bargh \& Ferguson, 2000; Janiszewski \& Wyer, 2014; Wheeler \& DeMarree, 2009; Wheeler, DeMarree, \& Petty, 2007). Generally speaking, the studies on automatism in buying have used the paradigm of priming in inductions of automatism, rather than expertise or training of this consumer (Chartrand \& Fitzsimons, 2011; Janiszewski \& Wyer, 2014). In other words, the most common research paradigm is that the consumer responds to a message without noticing it, automatically; the second paradigm refers to the consumer who buys without noticing because he is highly trained to do so.

Automatic behavior is that which does not overload the higher mental processes, that is, the person is able to behave thinking about any other thing (without using the conscious cognitive apparatus), responding almost directly to the stimulus (Chartrand \& Fitzsimons, 2011; Fiske \& Taylor, 2008). This behavior varies in relation to (a) the stimulus presented (e.g, the range of products for coloring one's hair) (Aarts \& Dijksterhuis, 2003; Foxall, 2007); (b) the expertise in buying which diverges with training in exercising the activity, e.g., somebody who dyes their hair fortnightly (highly trained, or expert) has greater experience in comparison with a person who dyes their hair twice a year (who may be considered a layperson in this task) (Anderson, 2004); and (c) the subject's internal variables (life history and cognitive processes) (Foxall, 2007; Petty, DeMarree, Briñol, Horcajo, \& Strathman, 2008).

Expertise is considered the last of the three stages of development of a skill (Anderson, 2004). There is a gap in the literature in relation to expertise in buying. The studies are usually related to the acquisition of a second language, or to the resolution of mathematical problems or similar (e.g., chess), but data was not found in the literature reporting on expertise in routine purchasing behaviors. Below, we present an adapted model which will be used in the present study as an interpretive basis for this type of buying.

The model of buying used here is derived and adapted from the Behavioral Perspective Model (Foxall, 2007). This model suggests two categories of variable as antecedents, and a further four as consequences. The category of antecedents is presented as a purchasing setting and learning history, and the consequences refer to the reinforcements and punishments. The setting consists of the physical, social and temporal elements of the environment. The learning history is the cumulative effect of the reinforcements and punishments of the past (Foxall, 2007). Reinforcements and punishments, therefore, may be considered both as antecedent and as indicators of the consequences. The reinforcing consequence has two dimensions: the informative, relating to social feedback, and the utilitarian, relating to the functionality of the product or service itself, not involving social feedback.

Based on this model, an interpretation was made including cognitive variables for operationalization and measuring of the process of routine purchasing. Thus, in the setting, as well as physical, social and temporal elements, we included all that 
was in the long-term memory or in the working memory which can introduce the behavior, but which has the characteristic of having come from outside the individual, such as, for example, priming. It is possible, on the other hand, to interpret the learning history more broadly, including variables of self and cognitive variables, suggested by Foxall himself (2010) in describing possibilities for applying the model.

In relation to the consequences categories, in this case, the interpretation is that they are not limited only to those which are observable or manifested. However, we include here reports related to the consequences, whether they are expected, have already been experienced, or describe the behavior or beliefs regarding what has occurred or what will occur. For example, the consequence of dyeing hair may be praise which occurred, which the person expects to receive, or which the person has received in the past.

The present work proposes to combine the individual variables and those of the purchasing setting, applied to the study of the purchasing of cosmetic products. The individual variables chosen for this exploratory study were those already described in the international literature (e.g. social norms of appearance, self-concept, antecedents etc.) (Dittmar, 2008). As similar studies were not found in Brazil, the decision was made to replicate that presented. The purchasing of this kind of product is routinized and common for women, which justifies the researchers' choice of this for the study. The other rationale is the economic relevance, as Brazil is the world's third largest consumer of cosmetics (Euromonitor, 2012), which also points to their social and cultural relevance. It has an economic relevance as it creates work; social relevance, as one can talk of compulsive buying; and cultural, as it can be seen as a manifestation of Brazilian culture (Tamayo, 1994), remembering that culture has been recognized as a variable which affects purchasing, even when it is automatized (Wheeler, Smeesters, \& Kay, 2011).

In order to work with expertise, it was necessary to undertake an exploratory and correlational study with the objective of describing the relationship between the reports of behaviors linked to the consumption of esthetics (operationalized in the four variables: commenting, getting information, using products and cosmetic services), and the individual variables and the variables of the purchasing setting which are directed towards beauty.

\section{Method}

\section{Participants}

A total of 953 women, over 18 years old and resident in Brazil, answered an electronic questionnaire. The mean age was 33.04 years $(S D=11.51)$; personal income was between 2000 and 4000 Brazilian reais (between 4 and 8 minimum salaries, in 2011); $41.7 \%$ were single, and $34.7 \%$ married; $37.6 \%$ were undergraduate students, and $22.5 \%$ were educated to senior high school level. Regarding the states of the Brazilian Federation, the largest participation was from the Distrito Federal (39.8\%); only representatives from the states of Acre, Amapá and Roraima did not participate in the sample, with persons from the other 24 states participating. In terms of the predominant self-declared ethnic groups, Caucasians represented $45.4 \%$ of the sample, followed by 'mixed' (without predominance of ethnic group perceived by the respondent), with $28.9 \%$. Among the professions, $29.7 \%$ were public servants, followed by professionals $(24.5 \%)$, students $(22.5 \%)$ and others (23.3\%).

\section{Instruments}

The following instruments and measurements were used: Measurement of expertise, as a proxy for behaviour. The women were asked, in four different items, to report the frequency of their reading of semi-specialized magazines, discussions on beauty products, use of services (i.e. frequency of visits to a beauty salon) and use of beauty products. The response scale had six options: daily (6), weekly, monthly, biannually, once, never (1). It was interpreted that, the higher the frequency of the behavior, the more expert the participant was. These four items were the study's dependent variables.

Scenario. Measurement of perception and internalization of body norms (Hirata, Pérez-Nebra, \& Pilati, 2012) containing two factors: Internalization and Intention of Behavior $(N$ items $=22$, Cronbach's alphas of .81 and .87 respectively) measured on a five-point scale of agreement.

Learning history. Measurement of somatic selfconcept (Giavoni \& Tamayo, 2005) containing two factors: Negligence and Sensuality, totaling 16 items, with alphas of .72 and .92, evaluated on a five-point scale of agreement $(1=$ does not apply to 5 = strongly applies $)$.

Consequences. Measurement of consequences of appearance with four factors: Utilitarian Benefit, Informational Benefit, Utilitarian Punishment, and Informational Punishment (47 items, a five-point scale of agreement, alphas of .65; .91;.71 and .85) (Pérez-Nebra, 2010). In all the scales, an increasing numerical value indicates an increase in agreement or application.

Questionnaire on socio-demographic information. Age in years, educational level, type of work, marital status, income, skin color and data for calculation of Body Mass Index (height and weight).

\section{Procedure}

Data collection. The research team sent e-mails to participants from the group of the researchers' acquaintances. The email contained a letter with the research objectives and indication of the minimum age for participation (18 years completed). This letter requested that the recipient should complete the questionnaire and forward it to other friends (the snowball technique) (Snijders, 1992). The first page of the questionnaire referred to the terms of consent and, in sequence, the respondent filled out the questionnaire. The 
data were archived online and the researcher had access at the end to the complete database. Each IP was recorded and was blocked from responding to the questionnaire more than once, so as to avoid duplication.

Data analysis. A sequence of analyses was undertaken with the objective of predicting the descriptions of behavior related to the purchasing of cosmetics. The first stage was a descriptive analysis of the frequency of behavior. A second block of analyses was made up of inferential analyses, so as to seek the prediction of self-reporting of behavior. The first stage of this second block was undertaken with a complete sample, including a variable of expertise in this analysis. The second stage was undertaken with samples segmented into experts and laypersons. The decision to work with subsamples was taken due to the proposal that laypersons and experts present different relationships with the variables proposed in the model. In other words, that the relationship between the variables for the group of laypersons was different from the relationship with the group of experts.

The analyses of these three groups were similar: total sample, subsample of experts, and subsample of laypersons. Given the non-normal nature of the variables, that is, problems of assymetry - for both sides, such as kurtosis platykurtic and leptokurtic, rendered inviable any possibility of transformation of the variable which would allow the use of linear relations. The strategy adopted was the use of nonparametric statistics for association between variables. The decision was taken to use Spearman's correlation, instead of that of Kendall, due to the ease of its association with the Pearson correlation (Siegel \& Castellan, 2006). The cut-off criteria for the presentation of the correlations is that it should be over .29 for the intensity of the relationship to be, at least, moderate (Dancey \& Reidy, 2006).

\section{Ethical Considerations}

This work was approved by the Ethics Committee for Research in Human Sciences, of the Instituto de Ciências Humanas (CEP/IH) of the Universidade de Brasília on March 27, 2009.

\section{Results}

All the behaviors reported by the participants suggest high-frequency. That of reading about beauty had a mean of $3.15(S D=1.24)$, which means that the frequency of reading is close to monthly. Commenting about beauty has a frequency between fortnightly and monthly $(M=2.74 ; S D=1.22)$. Going to a beauty salon had a similar frequency, with a slightly higher standard deviation $(M=2.82 ; S D=1.51)$. The use of products, on the other hand, had an even higher frequency and standard deviation $(M=2.19 ; S D=1.65)$. The use of products presented a ' $\mathrm{U}$ curve', that is, many use them daily, and many do not use them. It is worth mentioning that the use of products did not present a variation in the group of experts (median $=1)$ and it was not possible to undertake analyses with this subgroup.

The correlations suggested a significant relationship between all the behaviors. However, given the size of the sample, it also used the criteria of magnitude of correlation over. 3 and not only significance. There is a relationship between reading and commenting on beauty $(r=.51$; $p<.01)$ as well as with use of products $(r=.34 ; p<.01$; $r=.36 ; p<.01$, respectively). Therefore, the only behavior which presented no relationship with the others is going to the beauty salon.

\section{Frequency of Reading About Beauty Products}

For the general sample, both the consequences of behavior and the setting were related to this variable. In the sample, no variable was shown to be related. None of the demographic variables were related to this variable, as shown in Table 1.

Table 1

Spearman Correlations for Frequency of Reading, Psychosocial and Demographic Variables by Sample

\begin{tabular}{lccccc}
\hline \multicolumn{2}{c}{ Total Sample } & \multicolumn{2}{c}{ Lay persons } & \multicolumn{2}{c}{ Experts } \\
\hline Variable & $\rho$ & Variable & $\rho$ & Variable & $\rho$ \\
\hline Utilitarian & $-.35^{* *}$ & -- & -- & -- & -- \\
$\begin{array}{l}\text { Punishment } \\
\text { Internalization of }\end{array}$ & $.31^{* *}$ & & & & \\
$\begin{array}{l}\text { Social Norm } \\
\text { Informational }\end{array}$ & $.30^{* *}$ & & & & \\
$\begin{array}{l}\text { Benefit } \\
\text { Intention of }\end{array}$ & & & & \\
Behavior & $.30^{* *}$ & & & \\
\hline
\end{tabular}

$* p<.05 . * * p<.001$.

\section{Frequency of Commenting With Friends Regarding Beauty Products}

Again, the psychosocial variables were the only ones related to the behavior. The group of laypersons did not present related variables. The experts, on the other hand, presented a greater Internalization of the Social Norm, as shown in Table 2.

Table 2

Spearman Correlations for Frequency of Commenting on Beauty Products, Psychosocial and Demographic Variables by Sample

\begin{tabular}{lccccc}
\hline \multicolumn{2}{c}{ Total Sample } & \multicolumn{2}{c}{ Lay persons } & \multicolumn{2}{c}{ Experts } \\
\hline Variable & $\rho$ & Variable & $\rho$ & Variable & $\rho$ \\
\hline $\begin{array}{l}\text { Internalization } \\
\text { of Social Norm } \\
\text { Informational }\end{array}$ & $.38^{* *}$ & -- & -- & $\begin{array}{c}\text { Internalization } \\
\text { of Social Norm }\end{array}$ & $.29 * *$ \\
$\begin{array}{l}\text { Benefit } \\
\text { Informational }\end{array}$ & $.35^{* *}$ & & & & \\
$\begin{array}{l}\text { Punishment } \\
\text { Intention of }\end{array}$ & $.30^{* *}$ & & & & \\
Behavior & $.30^{* *}$ & & & & \\
Utilitarian & & & & & \\
Punishment & $-.35^{* *}$ & & & & \\
$* p<.05 . * * p<.001$. & & & & \\
\end{tabular}




\section{Frequency of Going to the Beauty Salon}

Again, the consequences appear to be related. Differently from the other reports of behavior, for both the subsamples the Utilitarian Punishment appears to be related, that is, only people who perceive there to be little Utilitarian Punishment go to the salon. (Table 3).

Table 3

Spearman Correlations for Frequency of Going to the Beauty Salon, Psychosocial and Demographic Variables by Sample

\begin{tabular}{lccccc}
\hline \multicolumn{2}{c}{ Total Sample } & \multicolumn{2}{c}{ Lay persons } & \multicolumn{2}{c}{ Experts } \\
\hline Variable & $\rho$ & Variable & $\rho$ & Variable & $\rho$ \\
\hline Utilitarian & $-.37 * *$ & $\begin{array}{c}\text { Utilitarian } \\
\text { Punishment }\end{array}$ & $-.31^{* *}$ & $\begin{array}{c}\text { Utilitarian } \\
\text { Punishment }\end{array}$ & $-.29 * *$ \\
Punishment & $-29{ }^{*} p<.001$. & & & & \\
$* p<.05 . *$ & & &
\end{tabular}

\section{Frequency of Use of Beauty Products}

This data was also made up only of psychosocial variables. For the subsample of laypersons, the behavioral intention and the utilitarian benefit were not included in the analysis. In the subsample of experts, on the other hand, it was not possible to undertake analyses (Table 4).

Table 4

Spearman Correlation for Frequency of Use of Beauty Products, Psychosocial and Demographic Variables by Sample

\begin{tabular}{|c|c|c|c|c|c|}
\hline \multicolumn{2}{|c|}{ Total sample } & \multicolumn{2}{|c|}{ Lay persons } & \multicolumn{2}{|c|}{ Experts } \\
\hline Variable & $\rho$ & Variable & $\rho$ & Variable & $\rho$ \\
\hline $\begin{array}{l}\text { Utilitarian } \\
\text { Punishment }\end{array}$ & $-.46 * *$ & $\begin{array}{l}\text { Utilitarian } \\
\text { Punishment }\end{array}$ & $-.32 * *$ & -- & -- \\
\hline $\begin{array}{l}\text { Utilitarian } \\
\text { Benefit }\end{array}$ & $.35^{* *}$ & $\begin{array}{l}\text { Informational } \\
\text { Benefit }\end{array}$ & $.30 * *$ & & \\
\hline $\begin{array}{l}\text { Informational } \\
\text { Benefit }\end{array}$ & $.33 * *$ & $\begin{array}{l}\text { Internalization } \\
\text { of Social } \\
\text { Norm }\end{array}$ & $.34 * *$ & & \\
\hline $\begin{array}{l}\text { Internalization } \\
\text { of the Social } \\
\text { Norm }\end{array}$ & $.30 * *$ & & & & \\
\hline $\begin{array}{l}\text { Intention of } \\
\text { Behavior }\end{array}$ & $.30 * *$ & & & & \\
\hline
\end{tabular}

$* p<.05 . * * p<.001$.

In short, Utilitarian Punishment, that is, punishment of oneself, appeared in all the reports of behavior; the lower the perception of punishment, the greater the reporting of the behavior. The utilitarian and informational benefits, in other words, the perception of benefits for oneself, or social benefits and the Internalization of the Social Norm, or intention of behavior are inversely related, that is, the greater the perception of the benefits or internalization, the greater the reporting of the frequency of the behavior. The individual demographic variables do not appear related to the reports.

\section{Discussion}

This work aims to test an automatic model of buying. It may be noted that the perception of the consequences occurs recurrently in the four types of behavior, as well as in the purchasing setting. However, the variable of past history, in this case, somatic self-concept, was not related to any of the types of behavior measured. Another finding is that the demographic variables also do not appear related to the phenomenon.

The fact of self-concept not being related to any of the types of behavior may be explained in various ways. The first and most evident is that the past history has no relationship with the automatic behaviors, because the variables that come into play are from the consumer behavior, setting, and the consequences. This hypothesis can be refuted, as the consequences were measured at the same time and not after the consumer behavior. This is to say, we measure the indicators of consequences, as they are part of the past history of the individuals, and they seem to present a strong relationship with the behaviors. Another possibility is that the measured dimensions of self-concept, Negligence and Sensuality have no relationship with beauty-related behaviors. In other works related to esthetics and beauty, the function or purpose of the esthetics was related to other variables, such as well-being, but not to the improvement of the self-concept (e.g. Pérez-Nebra, Dias, $\&$ Torres, in press). Hence, it may be that the behaviors linked to appearance may not be directly linked to matters related to sexuality or intention of beauty, but rather to the woman feeling good about herself (related to the utilitarian dimensions of benefit and punishment). This hypothesis still needs to be tested in future studies investigating precisely this pattern of relationships.

Another point still to be discussed is the fact that the demographic data are not related to the behaviors. This data corroborates the findings of Miranda (2002): what seem to predict the women's behavior are the psychosocial variables. One curious data is also the lack of a relationship with income. Probably, the change is not in the type of service used, but rather in the informational level of the products and services paid for (Foxall, 2007; Pohl, Oliveira-Castro, Bertoldi, \& Lourenzo, 2006). The literature, however, has already indicated that the predictive power of the demographic segmentation is unclear (Wells, Chang, Oliveira-Castro, \& Pallister, 2010).

The relationship between the behaviors studied deserves explanation. Instruction, whether oral or written (reading and commenting on cosmetic products), seems to be related to the use of cosmetic products, but not to going to the beauty salon. This data is interesting, as the use of cosmetic products requires greater autonomy of the woman compared to going to the beauty salon, where a professional will undertake the service required, without the woman needing any previous knowledge. The behavior which demands the most previous knowledge (use of products) presents the 
clear application of operators, reading and commenting on products. The consequences, on the other hand, appear in this work as adequate predictors of more automatic behaviors, corroborating the possibility of reinterpretation in the use of this model. The consequences predict the automatic behaviors in an expected way: lower punishment and greater benefit increase the reporting of behavior (Skinner, 1974). Nevertheless, there is a difference between the consequences that appear as predictors for each type of report of behavior: in the variables which require greater autonomy, one finds a greater number of predictors.

In the general analyses, the internalization of the social norm and the intention of behavior appear as a predictor of nearly all the behaviors, that is to say, the greater the perception of the norm, the greater the frequency of the behavior, corroborating Dittmar's findings (2008).

\section{Final Considerations}

The objective of this work - to test a model applied to the buying of cosmetic products - was achieved. The psychosocial variables best predicted the behaviors related to beauty. Laypersons and experts present different relationships between variables. This result has academic and managerial implications. There is evidence of corroboration with the models presented in the literature on routine buying and concerned with appearance, suggesting a greater predictive strength of the history of learning. The managerial implication refers to the type of segmentation to be used in this market. For this case, psychographic segmentation is more appropriate than demographic segmentation.

The impossibility of analyses for the case of the experts is related to the gap in the operationalization of this variable, such as, for example, women who use cosmetics more than once a day. One implication of this impossibility is social and clinical, as it is not known what predicts this behavior, as it is not known what could be done to modify its intensity. Another of this work's limitations - including the method used - relates to the absence of information on the type of heuristic used for each type of consumer. Further studies are necessary for closing this gap. Finally, it is understood that the behavioral description of the use of cosmetic products could be improved in future studies, as they appear with greater frequency than initially expected, rendering the analyses with this group inviable.

It is suggested that future studies should investigate different types of cosmetic products, using the division between colored and non-colored products, as these produce effects in the short and medium term, respectively. Colored products are typically make up, while those which are not colored are products for, for example, avoiding wrinkles. It may be that these types of products have differentiated frequencies and profiles, this proposal still being open for other types of routine purchases. Furthermore, one should include situational variables of the purchase, as the psychosocial and demographic variables presented a low relationship.

\section{References}

Aarts, H., \& Dijksterhuis, A. (2003). The silence of the library: Environment, situational norm, and social behavior. Journal of Personality and Social Psychology, 84(1), 18-28. doi:10.1037/0022-3514.84.1.18

Anderson, J. (2004). Psicologia cognitiva e suas implicações experimentais (D. C. Alencar, Trad.). São Paulo, SP: LTC.

Bargh, J. A., \& Ferguson, M. J. (2000). Beyond behaviorism: On the automaticity of higher mental processes. Psychological Bulletin, 126(6), 925-945. doi:10.1037//0033-2909.126.6.925

Bos, M. W., Dijksterhuis, A., \& van Baaren, R. B. (2011). The benefits of "sleeping on things": Unconscious thought leads to automatic weighting. Journal of Consumer Psychology, 21(1), 4-8. doi:10.1016/j.jcps.2010.09.002

Chartrand, T. L. (2005). The role of conscious awareness in consumer behavior. Journal of Consumer Psychology, 15(3), 203-210. doi:10.1207/s15327663jcp1503_4

Chartrand, T. L., \& Fitzsimons, G. J. (2011). Nonconscious consumer psychology. Journal of Consumer Psychology, 21(1), 1-3. doi:10.1016/j.jcps.2010.12.001

Dancey, C. P., \& Reidy, J. (2006). Estatística sem matemática para psicologia: Usando SPSS para Windows (L. Viali, Trad., 3rd ed.). Porto Alegre, RS: Artmed.

Dijksterhuis, A. (2010). Automaticity and the unconscious. In S. T. Fiske, D. T. Gilbert, \& G. Lindzey (Eds.), Handbook of social psychology (5th ed., Vol. 1, pp. 228267). Hoboken, NJ: John Wiley \& Sons.

Dittmar, H. (2008). Consumer culture, identity and wellbeing: The search for the 'good life' and the 'body perfect'. Hove, England: Psychology Press.

Euromonitor. (2011). Toilet care in Brazil. Retrieved from $\mathrm{http}: / /$ www.euromonitor.com/toilet-care-in-brazil/report

Fiske, S. T., \& Taylor, S. E. (2008). Social cognition: From brains to culture. Boston, MA: McGraw-Hill Higher Education.

Foxall, G. R. (2007). Explaining consumer choice. New York, NY: Palgrave MacMillan.

Foxall, G. R. (2010). Invitation to consumer behavior analysis. Journal of Organizational Behavior Management, 30(2), 92-109. doi:10.1080/01608061003756307

Giavoni, A., \& Tamayo, A. (2005). Inventário feminino dos esquemas de gênero do autoconceito (IFEGA). Estudos de Psicologia (Natal), 10(1), 25-34. doi:10.1590/S1413294X2005000100004

Hirata, E., Pérez-Nebra, A. R., \& Pilati, R. (2012). Desenvolvimento e validação de escalas brasileiras de percepção e internalização de normas corporais. Psicologia: Reflexão e Crítica, 25(1), 48-59. doi:10.1590/ S0102-79722012000100007

Janiszewski, C., \& Wyer, R. S., Jr. (2014). Content and process priming: A review. Journal of Consumer Psychology, 24(1), 96-118. doi:10.1016/j.jcps.2013.05.006 
Miranda, A. P. C. (2002). Mitos femininos do cinema: Uma tipologia de consumidoras de moda. Fashion Theory, 1(1), 121-132.

Pérez-Nebra, A. R. (2010). Consumo de beleza: Um estudo da relação entre automatismo e comportamento (Unpublished doctoral dissertation). Universidade de Brasília, Brasília, DF.

Pérez-Nebra, A. R., Dias, M. B., \& Torres, C. V. (no prelo). Acessibilidade crônica e agenda setting: Interface entre a psicologia e a comunicação no estudo da beleza. Psicologia \& Sociedade.

Petty, R. E., DeMarree, K. G., Briñol, P., Horcajo, J., \& Strathman, A. J. (2008). Need for cognition can magnify or attenuate priming effects in social judgment. Personality and Social Psychology Bulletin, 34(7), 900912. doi:10.1177/0146167208316692

Pohl, R. H. B. F., Oliveira-Castro, J. M., Bertoldi, L., \& Lourenzo, A. L. (2006). Efeito do nível de benefício utilitário sobre a duração do comportamento de procura por produtos. Revista Psicologia: Organizações e Trabalho, 6(1), 233-264.

Siegel, S., \& Castellan, N. J. (2006). Estatística nãoparamétrica para ciências do comportamento (S. I. C. Carmona, Trad.). Porto Alegre. RS: Artmed.

Simonson, I. (2005). In defense of consciousness: The role of conscious and unconscious inputs in consumer choice. Journal of Consumer Psychology, 15(3), 211-217. doi:10.1207/s15327663jcp1503_5

Skinner, B. F. (1974). About behaviorism. New York, NY: A. A. Knopf.

Snijders, T. A. B. (1992). Estimations on the basis of snowball samples: How to weight? Bulletin de Méthodologie Sociologique, (36), 59-70.

Sternberg, R. J. (2008). Psicologia cognitiva (R. C. Costa, Trad.). São Paulo, SP: Artmed.

Tamayo, A. (1994). Hierarquia de valores transculturais brasileiros. Psicologia: Teoria e Pesquisa, 10(2), 269-285.

Wells, V. K., Chang, S. W., Oliveira-Castro, J. M., \& Pallister, J. (2010). Market segmentation in behavioral perspective. Journal of Organizational Behavior Management, 30(2), 176-198. doi:10.1080/01608061003756505

Wheeler, S. C., \& DeMarree, K. G. (2009). Multiple mechanisms of prime-to-behavior effects. Social and Personality Psychology Compass, 3(4), 566-581. doi:10.1111/j.1751-9004.2009.00187.x

Wheeler, S. C., DeMarree, K. G., \& Petty, R. E. (2007). Understanding the role of the self in prime-tobehavior effects: The active-self account. Personality and Social Psychology Review, 11(3), 234-261. doi:10.1177/1088868307302223

Wheeler, S. C., Smeesters, D., \& Kay, A. C. (2011). Culture modifies the operation of prime-to-behavior effects. Journal of Experimental Social Psychology, 47(4), 824829. doi:10.1016/j.jesp.2011.02.018
Amalia Raquel Pérez-Nebra is a Professor of the Faculdade de Ciências da Educação e Saúde at the Centro Universitário de Brasília.

Cláudio Vaz Torres is a Professor at the Instituto de Psicologia at the Universidade de Brasília.

Received: Dec. 2, 2012

1st Revision: Apr. 21, 2014

Approved: June 13, 2014
How to cite this article:

Pérez-Nebra, A. R., \& Torres, C. V. (2014). Expertise in automatism study: An application in the consumption of esthetics. Paidéia (Ribeirão Preto), 24(58), 205-211. doi: 10.1590/1982-43272458201408 


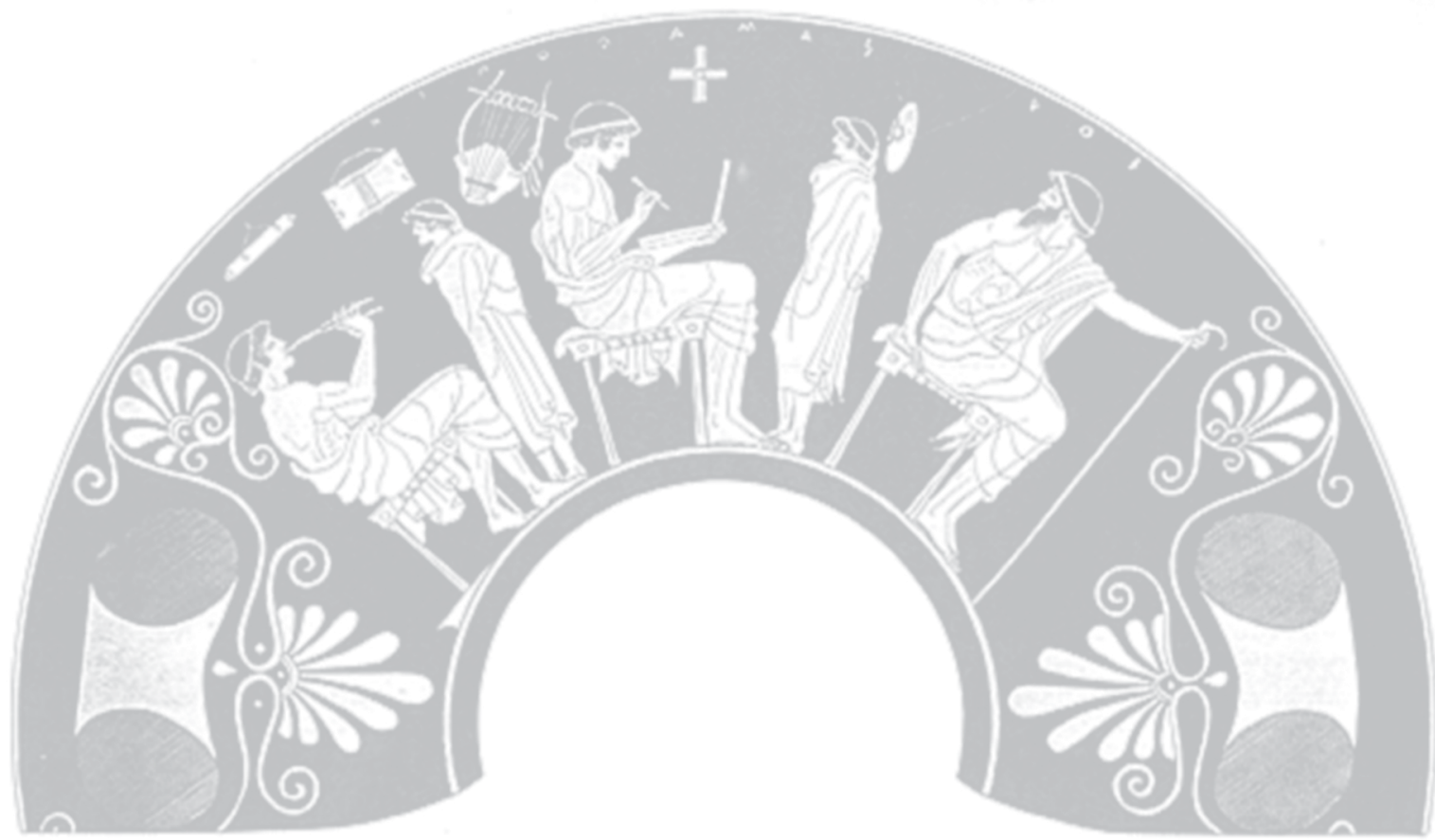

